\title{
TRANSFORMASI NOVEL CINTA SUCI ZAHRANA KARYA HABIBURAHMAN EL SHIRAZY MENJADI BENTUK FILM CINTA SUCI ZAHRANA : SEBUAH KAJIAN EKRANISASI
}

\author{
Imas Juidah \\ Program Studi Pendidikan Bahasa dan Sastra Indonesia \\ Universitas Wiralodra \\ Email: imas.juidah@unwir.ac.id
}

\begin{abstract}
ABSTRAK
Penelitian ini bertujuan untuk mendeskripsikan: (1) Proses ekranisasi pada aspek penciutan dalam novel Cinta Suci Zahrana Karya Habiburrahman El Shirazy menjadi bentuk film Cinta Suci Zahrana; (2) Proses ekranisasi pada aspek penambahan dalam novel Cinta Suci Zahrana Habiburrahman El Shirazy menjadi bentuk film Cinta Suci Zahrana; (3)Proses ekranisasi pada aspek perubahan bervariasi dalam novel Cinta Suci Zahrana Habiburrahman El Shirazy menjadi bentuk film Cinta Suci Zahrana. Metode penelitian yang digunakan dalam penelitian ini adalah deskriptif kualitatif. Data dalam penelitian ini adalah kata-kata, kalimat, dan kutipan yang terdapat dalm noveldan film Cinta Suci Zahrana. Sedangkan, sumber data dalam penelitian ini adalah novel Cinta Suci Zahrana karya Habiburrahman El Shirazy yang diterbitkan oleh Republika Penerbit pada tahun 2017 sebanyak 257 lembar. Hasil penelitian menunjukkan bahwa terdapat peristiwa yang sengaja dihilangkan, ditambahkan, dan diubah sesuai kebutuhan dalam film. Perubahan-perubahan yang terjadi pada proses ekranisasi dari novel ke film menghasilkan perubahan-perubahan pada aspek penciutan, penambahan, dan perubahan variasi. Aspek penciutan pada peristiwa ditemukan sebanyak 23 penciutan, aspek penciutan pada tokoh ditemukan sebanyak delapan tokoh, dan aspek penciutan pada latar ditemukan sebanyak tiga belas latar. Aspek penambahan pada tokoh ditemukan sebanyak dua tokoh. Aspek perubahan variasi pada penokohan atau karakter dan latar ditemukan sebanyak satu perubahan variasi, dan perubahan variasi pada saat adegan ditemukan sebanyak tiga adegan.
\end{abstract}

\section{Kata kunci: Ekranisasi, Novel, Film, Cinta Suci Zahrana.}

\section{PENDAHULUAN}

Fenomena perubahan karya sastra ke dalam bentuk film telah terjadi sejak beberapa dekade. Sejumlah film yang sukses, khususnya dari segi jumlah penonton dan apresiasi masyarakat, merupakan film yang diangkat dari karya sastra khususnya novel. Sementara itu, di Indonesia perubahan karya sastra ke dalam bentuk film juga telah lama dilakukan. Setidaknya pada tahun 1951 telah dilakukan proses adaptasi dari novel ke dalam bentuk film yaitu ketika sutradara Huyung memfilmkan drama yang berjudul Antara Bumi dan Langit karya Armijn Pane
(Eneste, 1991: 9). Perkembangan perfilman pada saat ini memang telah merambah masuk ke dalam dunia sastra dengan lahirnya sineas-sineas berbakat yang saat ini telah memproduksi film adaptasi dari novel.

Proses perubahan dari novel menjadi film memang dibutuhkan imajinasi dalam proses penggarapannya. Eagleton (via Faruk, 2001:35) mengatakan bahwa imajinasi adalah produk kekuatan spiritual manusia yang subjektif, yang tidak dapat dibatasi, tidak hanya oleh realitas melainkan bahkan oleh kontrol pikiran sadar manusia. Dari hal 
itulah muncul gagasan mengenai otonomi karya sastra sebagai representrasi yang paling sempurna dari kekuatan imajinasi tersebut. Oleh sebab itu, dalam proses adaptasi memang diperlukan adanya imajinasi sehingga bisa jadi akan terdapat perubahan-perubahan dalam proses adaptasi tersebut. Perubahan-perubahan tersebut memang wajar dilakukan dan mau tidak mau tentu dalam pembuatan film, yaitu bahwa film bukan lagi merupakan sentral budaya tetapi film telah menjadi bagian dari budaya pop lainnya, seperti buku, musik, dan lainlain (Nugroho, 1995:154).

Film yang diadaptasi dari novel tentu saja akan mengalami perubahan fungsi. Perubahan tersebut merupakan akibat dari perubahan alat-alat yang dipakai, yakni mengubah dunia kata-kata dalam novel menjadi dunia gambar-gambar yang bergerak berkelanjutan dalam film. Pemindahan wahana juga mempengaruhi perubahan ini, novel merupakan bentuk visual yang mengarahkan pembaca untuk mengandalkan pembayangan cerita sedangkan film merupakan bentuk audiovisual yang memberikan gambaran cerita kepada penikmat film dengan memadukan antara dialog dengan ekspresi pemain. Dengan perubahan-perubahan tersebut, pada umumnya penonton akan membandingkan antara film dengan novel aslinya. Dengan membandingkan antara novel dan film, seringkali menimbulkan kekecewaan atau bisa juga kepuasan dalam hati penonton termasuk di dalamnya para penulis novel aslinya.

Perubahan-perubahan tersebut dilakukan tentu bukan tanpa alasan. Faktor film yang terkait dengan durasi menyebabkan para pekerja film harus kreatif untuk dapat memilih dan memilah peristiwa-peristiwa yang penting untuk difilmkan. Oleh karena itu, seringkali ditemui adanya pergeseran khususnya berkaitan dengan alur cerita. Dalam tokoh pun terkadang juga ditemukan perubahan. Hal tersebut dilakukan mengingat masing-masing (antara novel dan film) memiliki karakter yang menyesuaikan dengan fungsi dari media karya. Eneste (1991: 61-66) juga mengatakan pemindahan dari novel ke layar lebar atau film juga mau tidak mau akan menimbulkan proses penciutan, penambahan, dan perubahan bervariasi.Beberapa perubahan tersebut yang nantinya akan dibahas dalam kajian ekranisasi pada novel Cinta Suci Zahrana karya Habiburrahman El Shirazy.

Berdasarkan latar belakang masalah mengenai transformasi novel Cinta Suci Zahrana, maka dapat dirumuskan permasalahannya sebagai berikut: (1) Bagaimana proses ekranisasi pada aspek penciutan dalam novel Cinta Suci Zahrana Karya Habiburrahman El Shirazy menjadi bentuk film Cinta Suci Zahrana?; (2) Bagaimana proses ekranisasi pada aspek penambahan dalam novel Cinta Suci Zahrana Karya Habiburrahman El Shirazy menjadi bentuk film Cinta Suci Zahrana?; (3) Bagaimana proses ekranisasi pada aspek perubahan variasi dalam novel Cinta Suci Zahrana Karya Habiburrahman El Shirazy menjadi bentuk film Cinta Suci Zahrana. Berdasarkan uraian di atas, tujuan penelitian ini adalah untuk: (1) Mendeskripsikan proses ekranisasi pada aspek penciutan dalam novel Cinta Suci Zahrana Karya Habiburrahman El Shirazy menjadi bentuk film Cinta Suci Zahrana; (2) Mendeskripsikan proses ekranisasi pada aspek penambahan dalam novel Cinta Suci Zahrana Karya Habiburrahman El Shirazy menjadi bentuk film Cinta Suci Zahrana; (3) Mendeskripsikan proses ekranisasi pada aspek perubahan variasi dalam novel Cinta Suci Zahrana Karya Habiburrahman El Shirazy menjadi bentuk film Cinta Suci Zahrana.

\section{KAJIAN TEORI \\ Transformsi}

Para seniman sering melakukan transformasi dalam menciptakan karya sastra, misalnya transformasi dari puisi ke musik, transformasi dari film ke novel dan transformasi dari novel ke film.Menurut 
KBBI (edisi 4: 2008), transformasi adalah perubahan rupa (bentuk, sifat, fungsi). Selanjutnya, Nurgiyantoro (2007:18) mengemukakan, transformasi adalah perubahan suatu hal atau keadaan.Bentuk perubahan, ada kalanya berubah kata, kalimat, struktur, dan isi karya sastra (novel) itu sendiri.Selain itu transformasi juga bisa dikatakan, pemindahan atau pertukaran suatu bentuk ke bentuk lain, yang dapat menghilangkan, memindahkan, menambah, atau mengganti unsur seperti transformasi novel ke film. Bermacam-macam alasan mendasari proses transformasi dari novel ke film. Alasan-alasan tersebut antara lain karena sebuah novel sudah terkenal, sehingga masyarakat pada umumnya sudah tak asing lagi dengan cerita novel itu. Pada akhirnya, ketidakasingan tersebut mendukung aspek komersil.Alasan terakhir adalah karena ide cerita novel dianggap bagus oleh masyarakat dan penulis skenario film. Munculnya fenomena pengadaptasian novel ke bentuk film merupakan perubahan substansi dari wacana yang memunculkan istilah ekranisasi.

\section{Ekranisasi}

Transformasi dari karya sastra ke bentuk film dikenal dengan istilah ekranisasi. Istilah ini berasal dari bahasa Prancis, écran yang berarti 'layar'. Ekranisasi adalah pelayar putihan atau pemindahan atau pengangkatan sebuah novel ke dalam film. Eneste (1991:60-61) menambahkan yang dimaksud dengan ekranisasi adalah pelayar putihan atau pemindahan atau pengangkatan sebuah novel ke dalam film (ecran dalam bahasa Perancis berarti layar). Pemindahan novel ke layar putih mau tidak mau mengakibatkan timbulnya berbagai perubahan. Oleh sebab itu dapat dikatakan, ekranisasi adalah proses perubahan bisa mengalami penciutan, penambahan dan perubahan dengan sejumlah variasi. Alat utama dalam novel adalah katakata, segala sesuatu disampaikan dengan kata-kata. Cerita, alur, penokohan, latar, suasana, dan gaya sebuah novel dibangun dengan kata-kata. Pemindahan novel ke layar putih, berarti terjadinya perubahan pada alat- alat yang dipakai, yakni mengubah dunia kata-kata menjadi dunia gambar-gambar yang bergerak berkelanjutan. Sebab di dalam film, cerita, alur, penokohan, latar, suasana dan gaya diungkapkan melalui gambargambar yang bergerak berkelanjutan. Apa yang tadinya dilukiskan atau diungkapkan dengan katakata, kini harus diterjemahkan ke dunia gambar-gambar.

Eneste (1991:60-61) menyatakan bahwa pada proses penggarapannya pun terjadi perubahan. Novel adalah kreasi individual dan merupakan hasil kerja perseorangan. Seseorang yang mempunyai pengalaman, pemikiran, ide, atau hal lain, dapat saja menuliskannya di atas kertas dan jadilah sebuah novel yang siap untuk dibaca atau tidak dibaca orang lain. Tidak demikian pembuatan film.Film merupakan hasil kerja gotong royong. Bagus tidaknya sebuah film, banyak bergantung pada keharmonisan kerja unit-unit di dalamnya: produser, penulis skenario, sutradara, juru kamera, penata artistik, perekam suara, para pemain, dan lain-lain. Dengan kata lain, ekranisasi berarti proses perubahan dari sesuatu yang dihasilkan secara individual menjadi sesuatu yang dihasilkan secara bersama-sama (gotong-royong).

Eneste (1991: 61-66) mengatakan pemindahan dari novel ke layar lebar atau film mau tidak mau akan menmbulkan berbagai perubahan dalam film, perubahan tersebut sebagai berikut.

\section{Penciutan}

Penciutan yang terjadi pada proses ekranisasi berarti juga apa yang bisa dinikmati berjamjam atau berhari-hari harus diubah menjadi apa yang dinikmati atau ditonton selama sembilan puluh atau seratus menit. Dengan kata lain, novel-novel yang tebal yang beratus-ratus halaman mau tidak mau harus mengalami pemotongan atau penciutan bila akan difilmkan. Hal itu berarti tidak semua hal yang diungkapkan dalam novel akan dijumpai pula dalam film. Sebagai alur, tokoh, latar, ataupun unsur lainnya yang ada dalam novel akan ditemui dalam film. Biasanya pembuat film (penulis skenario 
atau sutradara) telah memilih bagian-bagian atau informasi-informasi yang dianggap penting untuk ditampilkan.

Ada beberapa kemungkinan mengapa dilakukan adanya penciutan atau pemotongan. Pertama, dalam pemilihan peristiwa ada beberapa adegan yang dirasa tidak penting untuk ditampilkan sehingga sutradara menghilangkan beberapa adegan yang ada di dalam film. Kedua, dalam pemilihan tokoh pun terjadi hal yang sama. Ada beberapa tokoh dalam novel yang tidak ditampilkan dalam film. Film hanya menampilkan tokoh-tokoh yang dianggap penting saja karena keterbatasan teknis maka yang ditampilkan hanyalah tokoh yang memiliki pengaruh dalam jalannya cerita. Ketiga, dalam hal latar juga biasanya tidak semua latar akan ditampilkan dalam film kemungkinan besar jika semua latar ditampilkan akan menjadi film yang memiliki durasi yang panjang. Dalam mengekranisasi latar pun mengalami penciutan oleh sebab itu yang ditampilkan dalam film hanyalah latar yang pentingpenting saja yang mempunyai pengaruh dalam cerita (Eneste, 1991: 61-64).

\section{Penambahan}

Penambahan-penambahan yang terjadi dalam proses ekranisasi biasanya dilakukan oleh penulis skenario atau sutradara karena mereka telah menafsirkan novel yang akan mereka filmkan sehingga akan terjadi penambahan di sana-sini. Penambahan misalnya terjadi pada alur, penokohan, latar atau suasana. Banyak pula dalam proses ekranisasi, terdapat cerita atau adegan yang dalam novel tidak ditampilkan tetapi dalam film ditampilkan di samping adanya pengurangan tokoh, dalam ekranisasi juga memungkinkan adanya penambahan tokoh yang dalam novel tidak dijumpai sama sekali tetapi dalam film ditampilkan. Latar pun juga tidak luput adanya penambahan, dalam film seringkali dijumpai adanya latar yang ditampilkan tetapi dalam novel tidak ditampilkan.

Menurut Eneste (1991: 64-65) penambahan dalam proses ekranisasi tentu mempunyai alasan. Misalnya, dikatakan bahwa penambahan itu penting jika dilihat dari sudut film. Selain itu, penambahan dilakukan karena masih relevan cerita secara keseluruhan.

\section{Perubahan Variasi}

Selain adanya penciutan dan penambahan, dalam ekranisasi juga memungkinkan terjadinya varisi-variasi tertentu dalam film. Walaupun terjadi variasi-variasi antara novel dan film, biasanya tema atau amanat dalam novel masih tersampaikan setelah difilmkan. Menurut Eneste (1991: 66) novel bukanlah dalih atau alasan bagi pembuatan film, tetapi novel betul-betul hendak dipindahkan ke media lain yakni film. Karena perbedaan alat-alat yang digunakan, terjadilah variasivariasi yang terbatas sehingga penonton tidak bosan untuk tetap menikmati sampai akhir sehingga tidak semua hal atau persoalan yang ada dalam novel dapat dipindahkan semua ke dalam film.

\section{Novel}

Novel dapat mengemukakan sesuatu secara bebas, menyajikan sesuatu secara lebih banyak, lebih rinci, lebih detail, dan lebih banyak melibatkan berbagai permasalahan yang lebih kompleks. Hal itu mencakup beberapa unsur cerita yang membangun novel itu (Nurgiantoro, 1995: 11). Sayuti (2000: 10-11) mengemukakan bahwa novel cenderung expands "meluas". Jika cerpen lebih mengutamakan intensita, novel yang baik cenderung menitikberatkan munculnya kompleksitas. Sebuah novel jelas tidak akan selesai dibaca dalam sekali baca saja. Karena panjangnya, novel secara khusus memiliki peluang yang cukup untuk mempermasalahkan karakter tokoh dalam sebuah perjalanan waktu dan kronologi.

\section{Film}

Eneste (1991: 60) menyatakan bahwa film adalah hasil kerja kolektif berinteraksi dan saling berkesinambungan satu sama lain untuk membentuk sebuah film. Unsur naratif adalah bahan (materi) yang akan diolah, sementara unsur sinematik adalah cara 
(gaya) untuk mengolahnya. Dalam film cerita, unsur naratif adalah perlakuan terhadap cerita filmnya. Sementara unsur sinematik adalah teknis pembentuk film.

\section{METODOLOGI PENELITIAN}

Metode penelitian yang digunakan dalam penelitian ini adalah deskriptif kualitatif. Data dalam penelitian ini adalah kata-kata, kalimat, dan kutipan yang terdapat dalm novel dan film Cinta Suci Zahrana. Sedangkan, sumber data dalam penelitian ini adalah novel Cinta Suci Zahrana karya Habiburrahman El Shirazy yang diterbitkan oleh Republika Penerbit pada tahun 2017 sebanyak 257 lembar. Film Cinta Suci Zahrana yang disutradarai oleh Chaerul Umam dan digarap oleh rumah produksi Sinemart Picture. Teknik pengumpulan data pada novel yang digunakan dalam penelitian ini adalah teknik baca dan catat. Sedangkan, teknik pengumpulan data pada film dilakukan dengan cara tonton dan catat.

\section{HASIL DAN PEMBAHASAN Penciutan/pengurangan}

Eneste (1991:61) mengungkapkan salah satu langkah yang ditempuh dalam proses transformasi sastra ke film adalah penciutan. Penciutan adalah pengurangan atau pemotongan unsur cerita karya sastra dalam proses transformasi. Penciutan dapat dilakukan terhadap unsur sastra seperti cerita, alur, tokoh, latar, maupun suasana. Dengan adanya proses penciutan atau pemotongan maka tidak semua hal yang diungkapkan dalam novel akan dijumpai pula dalam film. Adapun bagian novel yang tidak difilmkan yaitu Hatinya Berkabut dan Basah, Menekuri Diri, Harapan, Tiba di Beijing, Arti Cinta Ayah dan Ibu, Cemburu, Bingung dan Resah, Hari yang Kusut, Cinta Suci Zahrana.

\section{Penambahan}

Eneste (1991:65) menjelaskan bahwa kemungkinan yang dapat terjadi dalam proses transformasi sastra ke bentuk film adalah penambahan (perluasan). Seperti halnya dalam kreasi penciutan, dalam proses ini juga biasa terjadi pada ranah cerita, alur, penokohan, latar, maupun suasana. Penambahan yang dilakukan dalam proses ekranisasi ini tentu memiliki alasan, baik alasan pentingnya penambahan, alasan relevansinya dengan cerita secara keseluruhan, ataupun karena alasan lain. Penambahan-penambahan ketika Cinta Suci Zahrana dialih wahanakan menjadi film Cinta Suci Zahrana itu bervariatif dan yang lebih dominan adalah penambahan tempat, di antaranya adalah Jalan di depan sebuah warung, Tangga kampus menuju lantai dua, Depan ruang dekan, Halaman depan rumah Pak Munajat, Tempat tidur Pak Munajat, Depan pintu mushalla, Depan kantor STM Al Fattah, Proyek bangunan, Resepsionis rumah sakit, Pemakaman, Ruang dokter, dan Rumah Hasan, ruang aoudotorium.

\section{Perubahan Bervariasi \\ Perubahan Alur}

Perubahan alur yang terjadi ketika novel Cinta Suci Zahrana difilmkan adalah pada bagian awal. Karena bagian awal tidak difilmkan atau dihilangkan ketika difilmkan yaitu kemunculan konflik antara Zahrana, Bu Nuriyah dan Pak Munajat. Kemunculan konfliknya adalah perbedaan keinginan Zahrana dan kedua orangtuanya, setelah tamat SMP Zahrana ingin melanjutkan ke SMA terbaik di Kota Semarang sedangkan orangtuanya menginginkan Zahrana melanjutkan ke Pesantren. Di dalam film bagian awal adalah munculnya konflik antara Zahrana dengan Pak H.Karman ketika memberikan sambutan pa karman berlebihan memuji Zahrana karena kata-kata yang disampaikan pak H.Karman tidak mengenakkan bagi Zahrana. Dalam novel terdiri dari delapan belas sub-bab yang berjumlah 256 halaman sedangkan dalam film berdurasi 108 menit yang terdapat 52 adegan yang saya dapat saya analisis.

\section{Perubahan Latar}

Latar yang ada di dalam novel, baik itu latar tempat maupun latar waktu, tidak mungkin dibiarkan seperti yang ada di dalam novel oleh penulis skenario dan sutradara ketika 
novel akan ditransformasi menjadi film. Seni kreatifitas penulis skenario dan sutradara pasti akan membuat perubahan pada latar yang dianggap kurang cocok dan kurang menarik ketika novel difilmkan. Adapun latar tempat yang diubah ketika novel Cinta Suci Zahrana ditransformasi menjadi film Cinta Suci Zahrana di antaranya adalah Rumah Lina diganti toko buku milik Lina pada saat Rana menceritakaan masalah lamaran pak H. Karman Rana mengunjungi rumah Lina, tetapi dalam film latarnya diganti menjadi toko buku.Pada waktu itu Lina tidak berada di dalam rumahnya, Zahrana mendapat pesan dari Lina. Berikut ini kutipanya:

" salam. Rana, nanti malam aku sudah pulang, insya Allah.kau boleh datang ke rumah. Ini sudah di bandara Changi, siap terbang .Lina. "....

Ketenangan dari nasihat-nasihat Lina yang menentramkan.Biasanya itu punya sudut pandang yang berbeda, dan sering kali bijaksana.maka agendanya kini sudah jelas, yaitu pulang, istirahat dan setelah salat Isya meluncur ke Tembalang, kerumah Lina. Kalau perlu ia bisa tidur disana. Sementara dengan mengingat wajah Lina, ia bisa melupakan sejenak teror lamaran Sukarman yang selama ini mencekamnya. ( halaman 136-137) dalam film durasi waktu ke 15:20).

Rumah Zahrana diganti rumah makan, firasatnya benar. Lima hari setelah ia mengirim jawaban itu, bu Merlin datang kerumahnya. Saat itu ia masih mengambil cuti. Bu Merlin datang mimik serius.Mimik yang ditakuti oleh para bawahannya, apalagi para mahasiswa. Berikut ini kutipannya:

" Bu, tolong ibu juga mengerti saya. saya telah berusaha menata hati dan jiwa untuk menerima pa karman. saya tidak mau karena saya sudah terlambat menikah, lantas saya menikah untuk seolah-olah bahagia."

“ Apa Bu? Mundur?'Zahrana menjawab dengan nada kaget.
"Iya, Zahrana.Sebaiknya kau mengundurkan diri saja.

Itu saranku sebagai orang yang sangat paham peta politik dikampus."

"Tidak, Bu. jika itu terjadi ketidakadilan, akan saya lawan sampai titik darah penghabisan!"

"Zahrana, kamu ternyata tidak tahu benar peta politik kampus. Tidak tahu benar siapa pak karman. Jika kau nekat, itu ibarat ulo marani gitik. Zahrana akhirnya paham dengan apa yang disampaikan Bu Merlin.

"Baiklah, Bu. Saya mengerti akan saya pikirkan matang-matang saran ibu.saya sangat bertrima kasaih ."( halaman 179-181 dalam film menit ke 29:58).

Rumah Zahrana diganti toko buku, Zahrana malam itu setelah memeriksa tugas-tugas akhir anak didiknya Zahrana membuka komputer.ia hendak berselancar di dunia maya. ia ingin melihat apakah ada email yang masuk dan ada berita yang menarik. Baru saja menyalakan komputer hp-nya berdering berdering beberapa kali.Ada tiga SMS yang masuk.Ia membukanya, berikut ini kutipanya:
"sedang apa perawan tua?"
"ternyata jadi perawan tua itu indah."
"jangan-jangan jilbabmu itu kedok untuk menutupi daging tuamu yang sudah busuk di kerubung lalat!"'(halaman 198-201 dalam film menit ke 34:45).

Ruang tamu diganti beranda rumah Bu Nyai, keesokaannya ia nekat mengajak lina menghadap bu nyai dan pak kiai. Ia mengajak sahabatnya itu, karena Lina dulu pernah nyantri di pesantren ARIS Kaliwungu. lina tentu lebih tahu berdiplomasi dengan bu Nyai daripada dirinya yang sama sekali tidak pernah nyantri.Kedatangannya diterima bu Nyai dengan wajah menyejukkan.Bu Nyai Sa'adah Al Hafidhah adalah istri K.H. Amir 
Shadiq Aresan, pengasuh utama pesantren $\mathrm{Al}$ Fatah. Berikut ini kutipanya: "Apa yang bisa Umii bantu, Anakku? Oh ya siapa namamu, Anakku?" tanya bu Nyai.

"Nama saya Rana, Umii.lengkapnya Dewi Zahrana.kedatangan saya ke sini pertama untuk silaturrahmi. Kedua untuk memohon tambahan doa dari Umii."

"Harus dihabiskan.kalau tidak habis itu namanya mubadzir. Dan mubadzir itu temannya setan," kata bunyai serius.Rana dan Lina hanya bisa manut saja. (halaman 205-207) dalam film durasi ke 57:38).

Dalam rumah diganti beranda rumah Zahrana, hari berikutnya Zahrana benarbenar tidak kemana-mana sejak pagi. Hari itu Zahrana ia izin tidak mengajar demi mengejar takdir. Ia menunggu diruang tamu. terkadang juga di beranda. sesekali ke jalan. Penjual kerupuk itu tidak juga datang. Jam sebelas siang seorang penjual kerupuk datang. (halaman 210-215menit ke 1:03:19).

Di akhir cerita dalam novel latar beradadi Tembok Besar China. YaituDua minggu setelah Idul Fitri, Zahrana membuka file kartu nama. Ia melihat sebuah nama Prof. Jiang daohan, yang tak lain adalah guru besar Fakultas Teknik Fudan University, Cina. Satu bulan setelah itu, Zahrana dan Hasan sudah sampai di Cina.mereka datang seminggu lebih awal dari hari yang dijadwalkan oleh Prof Jiang. Sebab mereka ingin merasakan indahnya bulan madu di Negri Tirai Bambu itu.Zahrana mengajak Hasan Mengiap di Hotel Jianguo.Sedangkan didalam film akhir cerita latar berada di Joglo Candi Prambanan. (halaman 245-249 menit ke 1:40:34).

\section{Perubahan Dialog}

Dialog panjang pasti akan dipotong dan diubah agar maksud yang terkandung di dalam dialog tersampaikan dengan maksimal. Teeuw (1994:170) mengatakan bahwa adakalanya konstruksi kalimat disederhanakan atau dipersingkat, tetapi apakah perubahan semacam itu mencerminkan dalam aturan bahasa, atau pilihan bahasa individual dari pihak penyunting. Adapun dialog yang diubah dari novel Cinta Suci Zahrana ketika difilmkan itu sangat bervariasi ada penambahan, pengurangan, dan perubahan variasi di antaranya Dialog Bu Merlin dengan Zahrana di kantin, berikut ini kutipan dialognya.

"Bu Rana cari Bu Merlin?"

"Iya"

"Penjaga kantin menunjuk ke ruangan khusus dosen.Zahrana mengangguk."

"Terima kasih Bu."

"Silahkan duduk Bu Rana. Saya sudah pesankan minuman kesukaan Bu Rana. Jahe hangat kan. Aku bilang begitu Bu Rana datang langsung dibuatkan biar masih hangat". Kata Bu Merlin. "Terima kasih Bu Merlin.Maaf ini seperti tidak biasanya. Ada keperluan apaya Bu Merlin meminta saya bertemu di sini?"

"Ada dua hal penting yang ingin saya bicarakan mewakili Pak Dekan."

“...” (halaman 110-113)

Ketika difilmkan dialog yang sangat panjang itu diubah hampir keseluruhannya, di dalam film $\mathrm{Bu}$ Merlin dan Zahrana hanya berdialog sangat simple, dan sangat singkat. Seperti berikut.singkat. Seperti berikut. "sudah ditunggu Bu Merlin Bu” kata petugas kantin. "Iya terimakasih."

\section{"Selamat pagi Bu Merlin"}

"Pagi"

"Dik Rana aku mau menyampaikan pesan dari Pak Karman” (menit ke 00:13:13-00:13:29)

Dua kutipan dialog di atas dapat diketahui pengurangan dan penghilangannya, seorang penulis skenario dan sutradara memikirkan bagaimana dialog yang sangat panjang dan dirasa tidak perlu diungkapkan semuanya ketika difilmkan maka sebagian dari dialog diubah bahkan dihilangkan, yang terpenting adalah apa yang hendak disampaikan kepada penonton itu tersampaikan dengan baik dan 
mudah dipahami, sehingga penonton tidak jenuh karena dialog yang panjang dan kurang mengesankan.

\section{Makna ekranisasi}

Eneste (1991:60-61) menyatakan bahwa pada proses penggarapannya pun terjadi perubahan. Novel adalah kreasi individual dan merupakan hasil kerja perseorangan. Seseorang yang mempunyai pengalaman, pemikiran, ide, atau hal lain, dapat saja menuliskannya di atas kertas dan jadilah sebuah novel yang siap untuk dibaca atau tidak dibaca orang lain. Tidak demikian pembuatan film.Film merupakan hasil kerja gotong royong. Bagus tidaknya sebuah film, banyak bergantung pada keharmonisan kerja unit-unit di dalamnya: produser, penulis skenario, sutradara, juru kamera, penata artistik, perekam suara, para pemain, dan lain-lain. Dengan kata lain, ekranisasi berarti proses perubahan dari sesuatu yang dihasilkan secara individual menjadi sesuatu yang dihasilkan secara bersama-sama (gotong-royong).

Suwardi Endraswara mengatakan bahwa karya sastra tidak sekadar sebagai dokumen imajinatif, melainkan memiliki dunia realitas, sastra yang sesungguhnya hasil khayalan pengarang, dapat memuat jutaan makna, (Endraswara, 2014:187). Suwardi Endraswara mengatakan pula bahwa sastra adalah sebuah renungan kehidupan yang mencakup multimakna, (Endraswara, 2014:186). Maka dari itu, karya sastra yang ditransformasikan akan menambah makna yang mungkin sulit untuk diungkapkan karena interpretasi yang bermacam-macam. Transformasi dari karya sastra menjadi karya seni lainakan menambah kuantitas dan kualitas secara regional, nasional, dan internasional. Karya sastra yang semula dicetak seribu eksamplar misalnya pada cetakan pertama kuantitasnya kurang diminati pembaca dan setelah ditransformasikan menjadi film kemudian sukses memikat hati penikmat film atau penonton. Dengan demikian karya sastra tersebut akan diburu pembaca karena dibuat penasaran oleh filmnya yang sukses memikat penggemarnya. Maka dengan demikian kualitas novel akan semakin meningkat dan berkembang pesat secara regional, nasional dan bahkan internasional.

Novel Cinta Suci Zahrana ditransformasikan menjadi film bertujuan agar amanat yang tersirat di dalam novel itu tersampaikan secara menyeluruh kepada masyarakat umum, tidak hanya diketahui oleh kaum intelektual yang menekuti bidang sastra saja. Seandainya novel Cinta Suci Zahrana tidak ditransformaikan menjadi film sudah pasti pesannya hanya akan diketahui oleh orang yang pandai membaca dan senang terhadap karya sastra terutama novel. Tetapi setelah ditransformasikan menjadi film, lapisan masyarakat yang buta huruf pun mengetahui pesan yang terkandung didalamnya.Masyarakat di Indonesia masih banyak yang buta huruf karena tidak sekolah atau karena krisis ekonomi ataupun karena pentingnya pendidikan belum tersampaikan kepada masyarakat di daerah terpencil. Dengan adanya media elektronik berupa televisi dan berkembangnya media komunikasi dan informasi maka masyarakat yang suka pada film akan mengetahui pesan yang hendak disampaikan oleh pengarang novel melalui transformasi di media televisi. Dengan adanya transformasi dalam kajian ekranisasi juga mengemas sebuah novel menjadi film menjadi sangat menarik karena dilakunan dengan menggunakan tiga aspek yaitu penciutan atau pengurangan, penambahan, dan penggunaan bervariasi.

\section{SIMPULAN}

Berdasarkan hasil penelitian yang telah dilakukan mengenai transformasi novel Cinta Suci Zahrana Habiburrahman El Shirazy menjadi bentuk film Cinta Suci Zahrana dapat disimpulkan bahwa melalui kajian ekranisasi terdapat perubahanperubahan pada aspek penciutan, penambahan, dan perubahan variasi. Aspek penciutan mengacu pada peristiwa di dalam novel yang tidak ditampilkan ke dalam film ditemukan sebanyak 23 penciutan, aspek penciutan mengacu pada tokoh dalam novel yang tidak ditampilkan kedalam film 
BAHTERA INDONESIA:

ISSN 2541-3252

Jurnal Penelitian Pendidikan Bahasa dan Sastra Indonesia

Vol. 3, No. 2, Sep. 2018

ditemukan sebanyak delapan tokoh, dan aspek penciutan mengacu pada latar dalam novel yang tidak ditampilkan kedalam film ditemukan sebanyak tiga belas latar. Aspek penambahan mengacu pada tokoh dalam novel tidak ditampilkan tapi ditampilkan dalam film ditemukan sebanyak dua tokoh. Aspek perubahan variasi mengacu pada penokohan atau karakter, mengacu pada latar, dan perubahan variasi pada saat adegan ditemukan sebanyak tiga adegan.

\section{DAFTAR PUSTAKA}

Eneste, Panusuk. 1991. Novel dan Film.Flores: Penerbit Nusa Indah.

Nurgiyantoro, Burhan. 2013. Teori Pengkajian Fiksi.Yogyakarta: Gadjah Mada University Press. Stanton, Robert. 2007. Teori Fiksi. Sugihastuti (Penerj). Yogyakarta: Pustaka Pelajar. 